\title{
Depiction of Animals as a Part of Royal Publicity in Ancient Egypt during the New Kingdom Period ${ }^{1}$
}

\section{Hatem Taha Ali}

Tourist Guidance Department, Faculty of Tourism and Hotels, Minia University

\begin{abstract}
Pictures invite the eye not to rush along, but instead to rest awhile and dwell with them in enjoyment of their revelation. Thus pictures played important role for making good propaganda in ancient Egypt. Scenes of animals particularly in aggression attitude are the main concern of this study. Thus images of conflict between animals and humans such as the harpooning of hippopotamuses, fowling in the marshes and the desert hunt, have been interpreted as iconographic references to the deceased of efforts in overcoming the chaotic forces.

This paper aims to highlight the utilization of animal scenes in the royal propaganda. It deals with the animal metaphoric representations and the aggression attitude from or towards them. This study classifies also the different depiction of animals at that context and it explores the symbolism of animal representation, particularly in the aggression scenes as royal publicity in ancient Egypt. The descriptive and analytical methodology is used to achieve the paper's aim.
\end{abstract}

\section{Introduction:}

Animals influenced every aspect of Egyptian life. Beyond their importance as primary source of food, materials and strength, their images and qualities also contributed to the Egyptians idiosyncratic form, ${ }^{2}$ and their religious concepts ${ }^{3}$. Animal in wall reliefs also have been considered a potential source of information about the religious and symbolic beliefs of the Egyptian people. Images of conflict between animals and humans such as the harpooning of hippopotamuses, fowling in the marshes and the desert hunt, have been interpreted as iconographic references to the deceased's efforts in overcoming chaotic forces. ${ }^{4}$ 
It was shown that ancient peoples practiced hunting animals, killing birds, and spearing fish primarily for providing themselves with meat and destroying animals which were the enemies of their children and enemies of their flocks, like with the ancient Egyptians continued to practice these activities during the various dynasties periods, while the purpose of the poor people was similar to that of their predecessors it appeared that the rich people cared little about what they might gain by these activities and probably they had recognized the danger of these animals on them and on their crops and then linked what these animals do in fact with that of their abroad enemies do in a symbolic unit . Searching in this symbolic unit is one of the aims behind these papers. Thus the study classifies different depiction of animals at this context.

\section{Classification of animal scenes:}

This study deals with the animal's metaphoric representation and the aggression attitude form or towards them. It will explore the animal appearance through the aggression attitude by classifying it into three main points:

-The king in the human form and the enemy in the animal form, hunt wild animals, fishing, and fowling enemies.

-The king in the animal form and the enemy in the human form.

-Both of them, the king and the enemy in the animal form.

\section{First the king in the human form and enemies in the animal form:}

This category may be classified into three sub-titles, hunting, fishing and fowling.

\section{A-Hunting}

Throughout history ancient Egyptians sought to establish order out of chaos. While this could be expressed in a variety of ways, one of the most common ways was that of the king hunt or catch one or more of the wield animals, some of this scenes belongs to one or more actual hunting scenes and the other was brought in other times to play a rhetorical role, this form the secret of it's beauty and it compose a new way of the Egyptian propaganda which it rests on an old orthodox as the king on behalf of the sun must constantly "wrest the cosmos from its persistent gravitation toward chaos". 5 This understanding applies to the orientation of the role of the hunting scenes in new kingdom 
temples whether the king is attacking human adversaries or hunting animals the king in this appearance is usually seen in the walls of the temple playing the role of the super hero as if he defending the "Lord of Maat" from the "forces of chaos"6. It is similar to our notion of modern super man duties in rescuing the world from the certain damage. This scenes held also to assure the king forces and abilities' when the people watch his hunting capabilities.

Many other explanations introduced for the rule of the hunting scenes as apart of aggression scenes representation as Assmann ${ }^{7}$ go far and interoperates that the Egyptians left no room for errant interpretations of the outcome of the battle and the Egyptians went to assure their victory after ending the battle by hunting some of the animals of this region. So hunting was an actual training to lead such troops into battle. Assmann furthermore identify sacrificial animals with chaos and address the concept "the enemies that the king slew or Osiris" ${ }^{8}$.

The first scene of the king in the human form hunts the enemies in the animal form appear of the king Knife handle from Gebel el-Arak (fig.1). ${ }^{9}$

This ambivalence of hunted and hunting wild animals endured through Egyptian history and has many parallels. The lion, the "king of beasts,' is the premier victim of the royal hunt ${ }^{10}$, the symbolic representation of the king grab a lion from it's tail with the animal turns its head towards the king back was the most discriminating see Tutankhamen (fig . 2), Tutankhamen appears grabs a lion from its tail, and with the other hand is shouldering the hatchet. Indeed the interchangeability of the scene which introduces the presentation of human enemies will eventually accompanied by the inscription h3st-nb -"Subjecting each foreign country". The skins of lions were often used for luxurious throws in the palace or home. Evidence suggests that Ramses II and III actually had a pet lion, which perhaps they hunted themselves ${ }^{11}$.

Tutankhamen is shown hunting gazelles in the desert (fig. 3)and one can see that the picture invokes the same imaginable reality. The desert gazelle was believed by the Egyptians to be the animal of Seth, The god who opposed Horus-principle that the later embodied. When gazelles are put out with the aid of hunting dog's, it symbolizing the Horus-principal; in much the same way as are the Nubians and Asiatics. Indeed, it is interesting to find that in the nearby scenes on the same painted chest depicting the defeat of these enemies of Egypt, hunting dog being shown helping the king in battle. As previously provided in these pictures there is a suggestion for some kind cosmic, and an archetypal hunt" enacted as much in battle as in the desert chase ${ }^{12}$. 
The king in the human form hunts the enemies in the animal form maybe inserted as a part of program intend to coupling between hunting and war scenes when the king Tutankhamen appear firing arrows into a melee of animals the chest by the attendants of his soldiers (fig.4).

Ramses III use the same program but by creating two opposite and parallel scenes of the hunting and fighting scenes through his temple in madenit Habu by hunting gazelles and zebras on one hand with the bulls and fighting lions on the other hand (fig 5,6).The final scene witch interprets the coupling between the hunting and fighting scene appear in the twenty second dynasty.

Indeed the bow used for the chase was very similar to that employed in war; the arrows were frequently the same, with metal heads, but some were tipped with stone, the mode of drawing the bow was also the same, the chasseurs sometimes pulled the string only to the breast, instead of the more perfect and more usual method of raising it, and bringing the arrow to the ear ${ }^{13}$.

The king in the human form hunts the enemies in the animal form may appear as the king lancing the lion (figs.7, 8). In the previous two scenes the king grabs the spear with both hands, with all of his strength in the butt. The lion, in the second example erect on his hind legs, still continues to attack the king.

Finally it must to remember that it is true that kings who were remembered as great warriors were also generally remembered as great hunters. Besides empires were always established by conquest, and the emperors who won them were always good fighters thus it appeared that hunting was the exercise of war.

\section{B- Fishing and fowling:}

The Nile and its canals were abundant with many types of fish, so fishing was a popular pastime, in addition to vegetables; fish was the primary food of most Egyptians. When fishing for food, the Egyptians threw large nets into the river and dragged in vast quantities of fish. Their catch was then prepared for eating by eviscerating the fish, drying them in salt, and leaving them in the sun. Egyptians used simple rafts for fishing and hunting on the river. ${ }^{14}$

The symbolic fishing which is carried out by using spears is one of this study's concerns. The fisherman stood on the papyrus skiff, waited for a fish to swim and at the most opportune moment thrust the spear into the water. In tomb scenes, the tomb owner is always shown with two fish on the end of his spear 
to showing that he can not only catch one fish but two with one thrust. Fishing here was a metaphor for imposing order on unruly nature and overcoming adverse circumstances. ${ }^{15}$

The tilapia fish were associated with sex and procreation as the tilapias method of incubating its eggs in its mouth then expelling the young paralleled with the Egyptian myths of creation in which the god Atum either spat out saliva or ejaculated in order to create humans from his own bodily liquid. In the New Kingdom, striped glass bottles take the shape of a tilalpia were prestigious containers for perfume. the sweet scents were signs of the gods .Indeed collecting,wearing, and smelling blue water lilies had erotic overtones, which is why all the woman in the scene are wearing and holding them; besides the Egyptian words for 'scent' and ejaculation sounded appeared similar which making this a visual and verbal pun as well ${ }^{16}$.

In contrast to the festival scenes, where children are generally excluded, however, the scenes of hunting in marsh are characterized by the attendants of children, wife ,may be because begetting children in eternity was also important or may be when the dead showed boating on the Nile with his children, or netting wild birds at the riverside with his wife by Magic, it believed, would bring these scenes to life again in the next world, and thus the noble would live on eternally, surrounded by the people and possessions that had been dear to him on earth ${ }^{17}$.

Another aspect hidden in the hunting and fishing scenes for the tomb-owner as a wealthy member of the propertied classes who could enjoy such pursuits in this world, without having to worry about food as such scenes preserved the same social status in the next world, which guarantee amusing of himself by using a throw stick to strike birds and a spear to catch fish ${ }^{18}$. Fishing for food on eternity was generally procured by fishermen's with nets, and they are also shown in these scenes. But these too can have symbolic functions as the nets caught not only the food for the dead tomb-owner, but also his enemies, rendering them harmless ${ }^{19}$. All of those previous elements are both strengthen and maintain the family cohesion or the order that they had been lived once before and explain why such scenes embodied scenes of order and hunting of chaos.

Hunting animals implied the elimination of chaos. The traditional royal act of smiting foes belongs to the signifying world the royal hunting scenes on temple walls must likewise be understood in this fashion, with animals signifying enemies. 
Animals here considered as a transitional stage used as a universal destruction ritual turns not only against foreign political enemies, but against evil ${ }^{20}$ the matter which is enhanced by the using of the bow and arrow in such fishing scene the matter which doesn't use in reality, (fig.9).

-Fowling was a favorite amusement of all classes. The ancient Egyptians seemed to use clap nets, traps, and throw-sticks in fowling. The professional fowlers used the nets and traps, the traps were generally made of network stretched over a frame consisting of two equal sides moving on a bar or axis. The trap was set with the bait put in the center of the bar. When the birds touched the bar both sides of the trap collapsed. Some other traps were found to have rounded edges or square frames ${ }^{21}$.

While the throw-stick was used like in the fishing scenes mainly by those who practiced fowling as a recreational activity, it was made like fishing also for the symbolic purposes.

Erman stated that the sportsman, in his fowling excursions used to stand upright in a boat, swinging his throw-stick in his hand with a strong throw through the air to knock one or more birds over into the water ${ }^{22}$. The same author also stated in describing the methods of fowling in ancient Egypt, that the fowlers appeared with tame cats which were trained to bring the fallen birds out of the thicket into the boat ${ }^{23}$.

\section{Cats as co actors on fowling scenes:}

Cats appear in the fowling scenes like wife appearance in the fishing scenes but cats appearance have to be discussed. The question about the inclusion of these images is whether they a re actually realistic representations of pets or types of religious symbols. In the tombs of New Kingdom nobility, cats are also depicted in hunting scenes, where they attack or capture birds. In the Third intermediate Period the domestic cat became associated with the gentle aspect of the lioness goddess Sakhmet. ${ }^{24}$.

\section{2- The king in the animal forms "Lion, Sphinx, and Bull form" and the enemies in the human form:}

\section{A- The king in the lion form:}

The animal forms taken by the gods and goddesses of ancient Egypt were not constant, however. Ancient Egyptian deities existed in a state of flux, and some of them could take many different forms even at different times. Amun- Ra "the king of the gods" in this last form was identified closely with Egypt's 
pharaohs, whom he supposedly protected when they led their armies on the field of battle. ${ }^{25}$.

One of the popular scenes is that scenes which depicting the king in the lion form or sphinx swallow or doing one or more of the humiliated acts to the enemies .The first scene of the king in the lion devours a human enemy appeared in (fig. 10), but the standard scene of this kind of representation during the new kingdom is appeared in the form of the king in the lion form swallow a human enemy who appeared pee from fear (fig.11).

The scenes depicting the king in the lionesses form catch or trample one of enemies it designed to refer to the solar identification with the legendary roots of the story of sacred cow, and to equate the royal role in the fight against the enemies of Egypt with the goddesses Sekhmet eternal role in the fight against the forces of chaos. ${ }^{26}$

The first of the scenes depicted the king in the lion form as a humiliated methods for the traditional enemies of Egypt in the first dynasty begin with the king Narmer in which the king appear in the lion form devouring one of the Egyptian state enemies (fig 10). ${ }^{27}$.

In the new kingdom the most master scenes of this representation depicting the king in the lion form swallow his enemy (fig.11). Amenhotep III appears in the first jubilee "like / as (or" the likeness of ') Re when he rises. ${ }^{28,}$

\section{B- The king in the sphinx form:}

Certain animals in ancient Egypt were combined with the human form in the forms which composed the deities. It was always the head of the animal which was united to a human body; the only converse instance of a human head on an animal body is the sphinxes form .It represents the king and not a god. Possibly the combination arose possibly from priests which was wearing in the past the heads of animals when personating the god ,as the high priest wore the ram skin when personating Amun. ${ }^{29}$ The sphinx that tramples Egypt's traditional enemy's forms a meaningful constellation may refer to the solar aspects of the sphinx that defeats the forces of chaos at the beginning of time. 30 
The role of the sphinx as a part of the aggression scenes begin on the outer temple walls and pylons as the king depicts everywhere and always supplied with ankh and w3s signs, in a signal to water being poured over the king by Horus and Seth, the medium through which he achieves a rebirth like/as the sun-god at the first dawn ${ }^{31}$, so the king is the creator god on the outer temple walls and pylons. And Parallel with the god inside the temple as well and when he perform the sanction ritual his divine creative force which passes to him at the instant of his solar birth, performs the temple rituals as the creator god, and when he moves within the temples he move as the sun disc itself ${ }^{32}$.

When Atum is combined with Ra; the creative force bass form Ra to -Atum, representing the manifestation of the creative force. Thus Ra-Atum is depicted in human form, carrying the ankh (life), and the was scepter (creative power).In human terms, Atum represents the moment that one passes from sleeping (unconscious state, subjective being) to wakening - becoming aware of one self and one's surroundings (gaining consciousness, objective being). It is like standing on solid ground again. It is the realization of existence ${ }^{33}$. In addition the pharaoh comes into being each morning as a new sun. This nature of pharaoh's identity as" Re and Atom" relates how the king in such an aspect functions appear in the temple "every day" 34 .

Thus Ockinga states that the sphinx regularly represented the king. since very early on and with the re-interpretation of the sphinx .The same matter continue in the new Kingdom as a text indicated that the king is seen as a living ssp image of the sun-god ${ }^{35}$, a relief of Seti I on the sphinx form offers two vessels of unguent to Amun Re. ${ }^{36}$ who tells Seti: "(I) have given to you the lifetime of Re. the years of Atum, you appearing upon the dais of jubilees like/as Re every day" "di.n(.i) n.k 'h' n R' rnpw.t n Itrn, '.t hr i3ty nt hb.w-sd ml R' r' nb".thus text suggests a daily renewal of the king as Re in daily jubilecs. ${ }^{37}$, So that the king rises every day like the son god inside the temple.

Thutmose IV appears as a sphinx trampling his enemy's (fig.12). ${ }^{38}$

The king Tutankhamen appears also as a sphinx trampling his enemy's (figs.13, 14). ${ }^{39}$.In the first scene the king Tutankhamen is seen trample two Nubians and Asiatic enemies lying in contorted posture on the ground under the bows of the Sphinx shaped king who pulled the head of the Nubian upwards while the face of the other is posed to enfaced the ground. At the base of the thicknesses of the doorway to Seti's I chapel at Abydos. ${ }^{40}$ Seti's ka offers ankh 
to the nose of Seti. Who appears as a recumbent sphinx adorned in the tef crown.

\section{C- The bull form:}

The nomadic ancestors of the Ancient Egyptians were dependent on their herds for survival. There is evidence that cattle were treated as sacred animals as early as the sixth millennium BCE. Cattle cults remained as a central part of Egyptian religion and mythology during the whole span of Pharaonic culture. Human beings were said to be "God's cattle." Bulls were revered as symbols of masculine strength and fertility. Many gods had a bull form, and sacred bulls were kept at some temples. A sky goddess who took the form of a cow was among the earliest of Egyptian deities. Cow goddess under all her names represented the loving and nurturing aspect of the divine. The king and later humanity in general, played the role of the calf of the divine cow. From early times the king of Egypt was compared with the leading bull of a herd, which's able to defeat all challengers. Bulls as fighters were particularly associated with the war god Montu, who was manifest on the earth as the Buchis bull. The white bull of Min embodied male sexuality. The mysterious process of heredity was celebrated in the concept of kings and gods being "the bulls of their mothers". 41

The Egyptians are unusual in having given a very positive association between the bull and fertility as the combination of majestic bull, upraised arms, and dripping phallus tend generally to be brought together whenever ' $\mathrm{ka}$ ' is used as an element in a divine name ${ }^{42}$. Sacred bulls were manifestations of power in Egypt in every era. The gods were called 'bulls of their reign, and even the king called himself the bull of his mother in proclaiming his rank and claims to the throne ${ }^{43}$.

the king appear in the shape of the bull (figs.15,16), the bull has thrown down an fortified settlement, the representative of country enemy appear lying on the ground in the second scene ,the second actor "the enemy" comes here in a desirable state of surrender. The open circle of walls and the broken-stones (or backs) can be recognize as a result of the homed bull action ,the opposition between his front legs on the ground firmly, be seated header indicates the impeding attack, while the enemy has already fallen to the ground ${ }^{44}$.

In addition Sphinx and gripping, there is also the bull trampling on the ship's cabin. This representation, however, is valid, but different examples are taken from the temple of Hatshepsut at Deir el-Bahri (figs 17, 18, 19). ${ }^{45}$ 
A wonderful scene is depicted at Medinet Habu, Ramses Ill's in his mortuary temple at Thebes which shows the king in the midst of a wild bull hunt. The king is riding his chariot with the reins of the horses tied around his waist, leaving his hands free to fire arrows at the animals. He has become so excited by the hunt that he has thrown his leg over the front of the chariot to give him more support while bracing him against the force of the bow. One bull that he has hit is already collapsed in the reeds ${ }^{46}$. Most hunting was for food, and catches provided tasty meals for the king, noblemen and their families.

It is obvious to note that the visual propaganda employed to promote the monarchy - the king as a lion, a giant scorpion, a fierce Catfish, a wild bull or a mace-wielding scorpion - was unashamedly brutal. It was for both promise and a warning ${ }^{47}$.

\section{Thirdly, the king and the enemy in the animal form:}

\section{The bull fighting:}

For the first time, which depicts the conflict by the percentage of parity between the qualitative king and enemies where depicts the scene of a rampaging bull butt another bull with a strong variability to the ground, it must to note that the artist did not overlook the details that appear in the color of skin of the bull and in the hair tails and even in the dung, which emerged at the back of edgy strongly as a result of conflict and its violence (fig.20).

The most disputable scene of this kind of presentation is in (fig.21), which held now in the British museum and shows a scene consists of lion and three ducks. It appear that the lines which the artist use in painting the head of the lion and ducks indicated the cleverness and the artistry ability of the painter himself where the artist could paint the head of the lion and ducks with the less lines, besides taken into account in drawing ratios legs and necks of ducks in addition to the ratios between them and the lion. It is known that ducks was the hieroglyphic symbol of the common people so the researcher asks if this scene express about enemies or the Egyptian public or it paint as a training sketch to control the proportion of the drawing ${ }^{48}$.

Another showed limestone scene the artist had wanted to express the fright and the intense fear which visually the artist was ordained in the animal "may be a hyena, which defecates suddenly horror as a result of the severity to see 
another strongest animal unfortunately large part missing from this piece (fig.22). ${ }^{49}$

Although there are scenes showing the king or enemies in the animal image there is scarcity in the scenes which gather the animal appearance to both of the king and animals in the same time and it focused in most of it times in the comparisons to the conditions of the country of weakness and humiliation this which is may be called the sarcastic propaganda which the researcher alleges that the ancient Egyptian was the outrigger to this kind of propaganda.

\section{The sarcastic propaganda:}

\section{The scene depicts Lynx bite of a lion}

The Lynx is a cat's platoon; it could be a leopard, it featured by a large head and a short tail. Theorist decree ink on limestone found near the cemetery number nine valley of the kings and now kept at the museum of Cairo showing Lynx bite of a lion this satirical sketch means that the weakest became dare than strongest (fig.23).

It presumably in fact that the contrast to be hold and that the lion to attack, this is a revolution over the traditional representation of the king and it express about the coup state of scales and the situation.

Its some kind of humor and it's a joke to draw the lion who plays chess with deer (fig.24), there is another fee on the British museum where a fox or a wolf is in the form of a shepherd sheep, plays the flute together with a two-pronged front of a herd of deer and protector of the form of a cat takes care of geese (fig.25).

There is no doubt that such expressions carry a great deal of freedom as at a time in which charioteer was a symbol of courage and strength, one can find that the artist paints a chariot driven by a mouse, or at other times by donkey who lead the boat .

\section{The purpose of animals Presence in aggression scenes:}


Scenes containing animal representation can be classified into two kind of presentation the first one is a purely rhetorical in nature in which the king appear in the human form catch one lion with one hand and is about to smite it with the other hand or that the king sometimes appear in the sphinx form trampling the enemies of Egypt in the human form such presence of foreigners on artifacts expresses the pharaoh's dominance over chaotic forces. In other times it invoked to represent a real incident of the king who's may appear in the human form stand in his chariot and hunt animals but it invoked in the same time to represent the chaotic forces represented in the animal trapped scenes. Hunting scenes purposes may be expanded to include (food, religious, political, and touting purposes $)^{50}$.

\section{Conclusion:}

It turns out that the effective dynamics of the ancient Egyptian Paintings is summarized in the self-creative intent of the ancient Egyptian belief of the direct relationship that exists between a thought and its manifestation, just as a phrase currently popular states, "if you can believe it, you can conceive it ,and if you can conceive it, you can achieve it." It appears exciting the graduated ambition for the director of the conflict scenes in the new kingdom representation as this study expressed the last stage of Egyptian photography and the last stage of creativity in the royal propaganda scenes by:

-It firstly distinguished by it's passing through out the frosty and solid representation of the smiting scenes.

-It also has gone beyond the symmetrical portrayal of both the king and the enemies in the human image.

-This stage had known it's way to the aesthetic value and the using of the analogy, the artist has refuged to represent one of the compartments of the image "the king or the enemies in the animal representation" this aesthetic composition of the image increase it's beauty and open the horizon for imagination.

-It clearly shown, the choice of each motif design is not accidental as each subject is chosen by mounting the pest appearance in the pest way of expressing .and also chosen by mounting location in specific event dependent as: 
*The king in the human form hunts the enemies in the animal form the king in this appearance is usually the role of what looked now " super man"as if he defending from the "forces of chaos" by defending the system and morals.The king in the human form hunts the enemies in the animal form may inserted as a part of program intend to coupling between hunting and war scenes by creating two opposite and parallel scenes of the hunting and fighting scenes or by inserting some icons in it's not usual places as the attendants of soldiers in hunting scenes, or by inserting of the enemies appearance as a symbols of a birds or fishes give the scenes two essentials features either the surrender or it's attempts to escape in some cases.

*The king in the animal forms "Lion, sphinx, and pull form" and the enemies in the human form was used to refer to the divine nature and the legendary roots of the mythical stories to equate the royal role in the fight against the enemies of Egypt with the first gods of creation .

*The representation of both of the king, and the enemy in the animal form these scenes were brought either to express the relative superiority of the Egyptian king in the fighting, or the difficulty exceed as in the example, which demonstrates the parallel efficiency in the fighting between a pair of bulls see figure which shows the scattered manure of one of the bulls indicative of the king's superiority by barely and difficulty on his opponent , or it focused in most of it times in the comparisons to the conditions of the country of weakness and humiliation this which is could the sarcastic propaganda For the state of debility and weakness

*This study indicates that the Egyptians by this time were interested in recording historical events in sequence in a manner that appealed to both their artistic sensibilities and ideological duties. 
List of figures:

Fig.1 Knife handle from Gebel el-Arak, after Wreszinski, 1932, A 441.

Fig 2 Tutankhamen appears grabs a lion from its tail, after Wreszinski, 1932), a459.

Fig 3 Tutankhamen hunts dessert gazelles, after Jeremy Naydler, 2009, p123.

Fig 4 Tutankhamen firs arrows into a melee of animals by the attendants of his soldiers, after Wreszinski, 1932, d96.

Figs.5,6 Ramses III example for coupling between the hunting and fighting scene, after Wreszinski, 1932, "d95, b56"

Figs 7, 8 sketch from TT143 and Ostrakon, ramasside the king lancing a lion, after Wreszinski, 1932, "b51, b52".

Fig 9 Tutankhamen fishing with the attendant of the solder icon, after Wreszinski, 1932, D113.

Fig 10 Narmer palette the king in the lion devours a human enemy, after, Elshamy M, 2015, p 62.

Fig 11 the standard scene of the king in the lion form devours the human enemy, after 1932,وليم هـ ـ بيك

Fig 12 Thutmose IV as a sphinx tramples his enemies, after after Wreszinski, 1932, E152.

Figs 13, 14 .The king Tutankhamen appears also as a sphinx trampling his enemy's, after, Wreszinski, 1932, E174.

Figs, 15, 16. The king appears in the bull form attacking a fortified enemies, after, Wreszinski, 1932, E318, E319, E320.

Figs 17, 18, 19 Examples of Hatshepsut's of bulls attacking scenes, temple at Deir el-Bahri, after Wreszinski, 1932, E321, E322, E287. 
Fig.20. The king and the enemy in the animal appearance "bull's form", after, Christopher Hayes W, 1990, p392.

Fig 21 The head of the lion and ducks, after,102,1932, وليم هـ ـ بيك.

Fig 22 A hyena defecates as a suddenly horror of the result for the severity to 279ص,1932, وليم هـ ـ بيك see another strongest animal, after,

2900.

Fig 24 the lion who plays chess with deer, after, صـ,1932, وليم هـ ـ بيكو.

Fig 25 a cat takes care of geese, after, صـ,1932,وليم هـ ـ بيكو 76 ص .
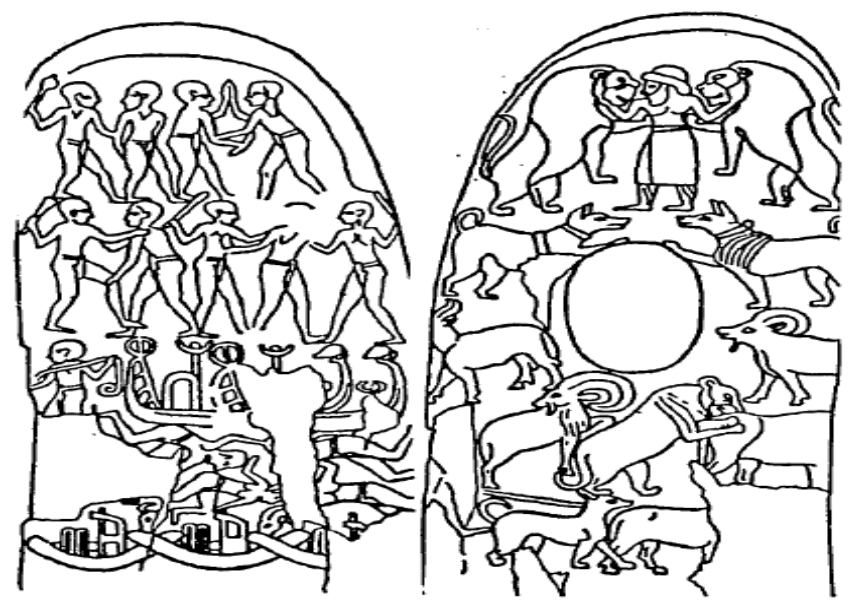

Fig

.1

Fig.

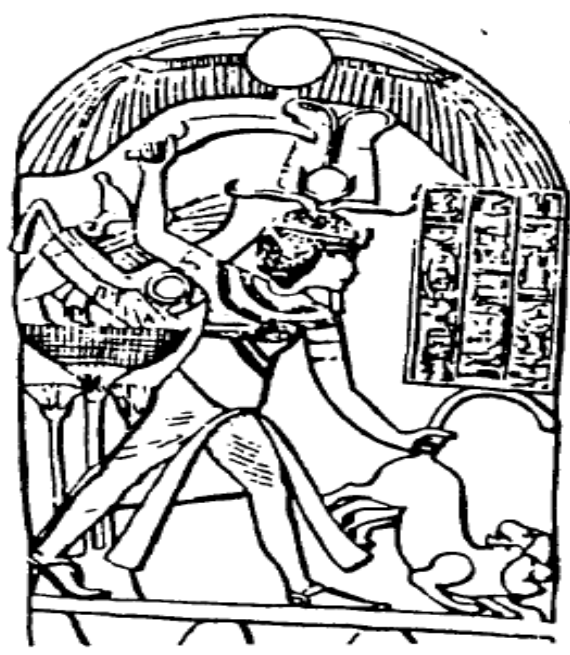



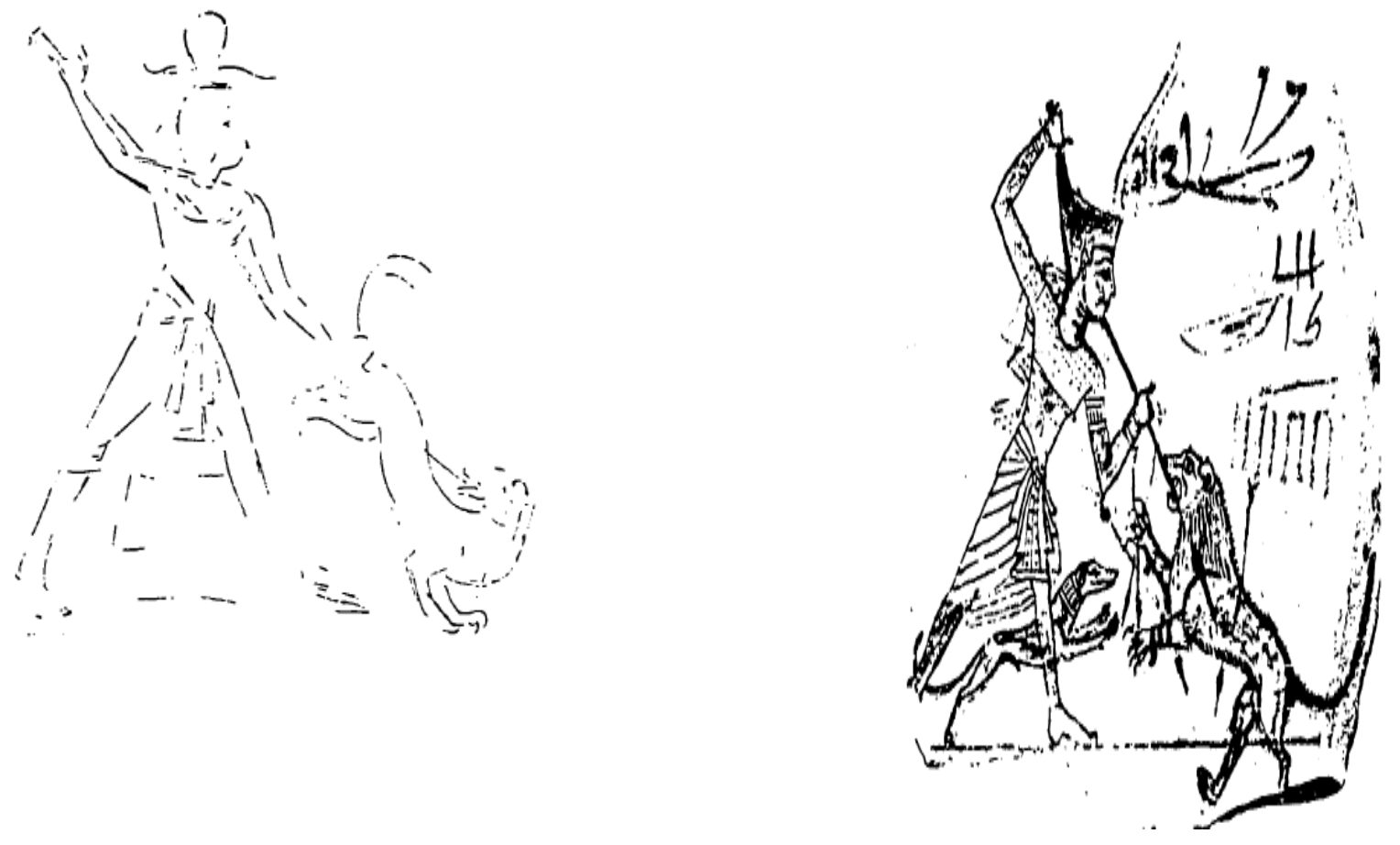

Fig.6 


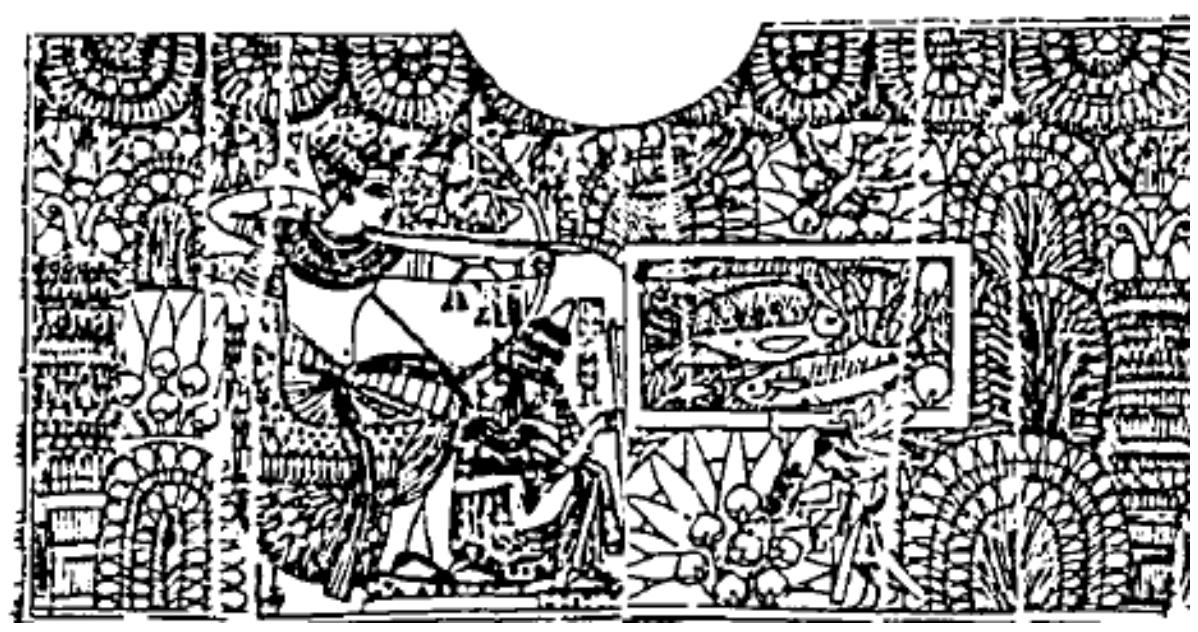

Fig. 9

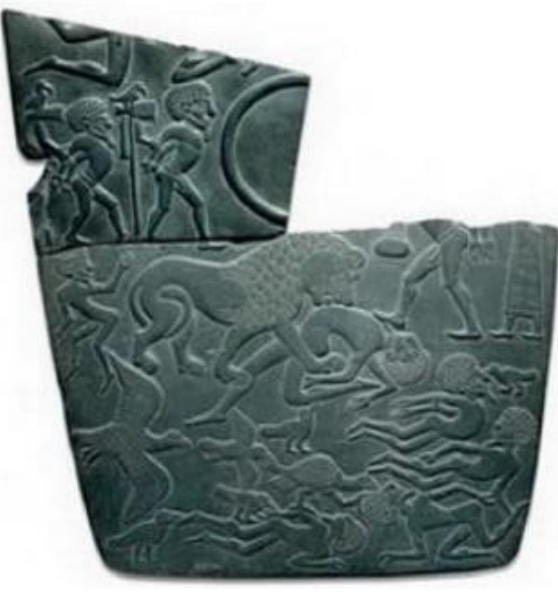

Fig. 10

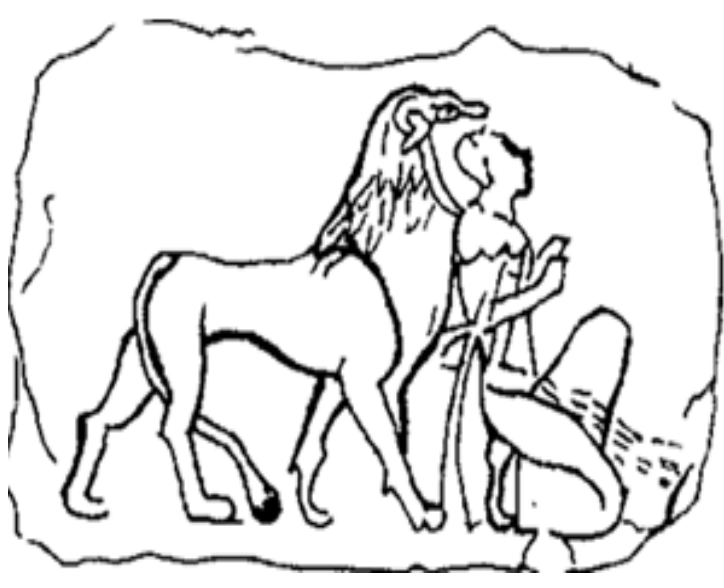

Fig. 11 


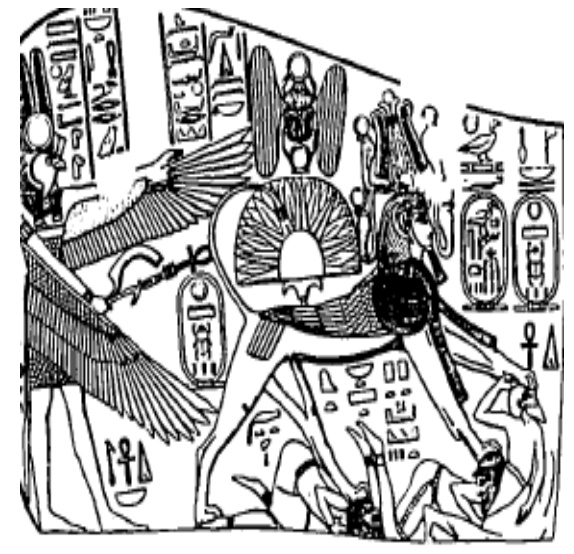

Fig.12

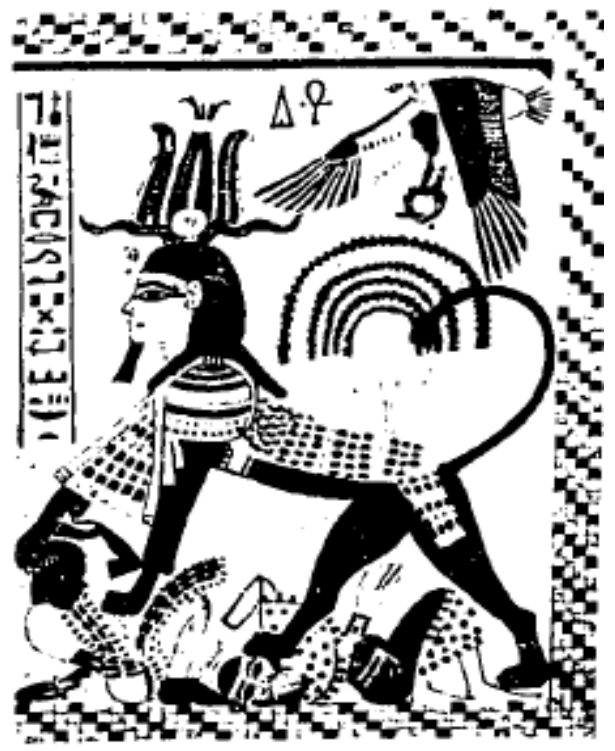

Fig.13 


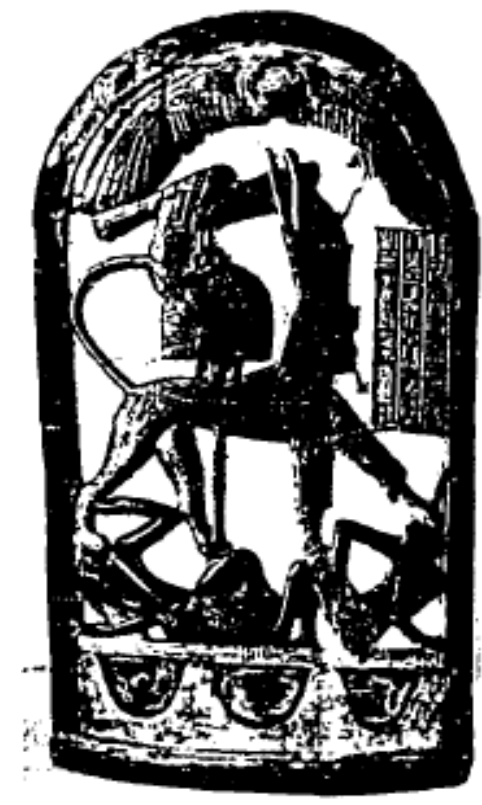

Fig.14

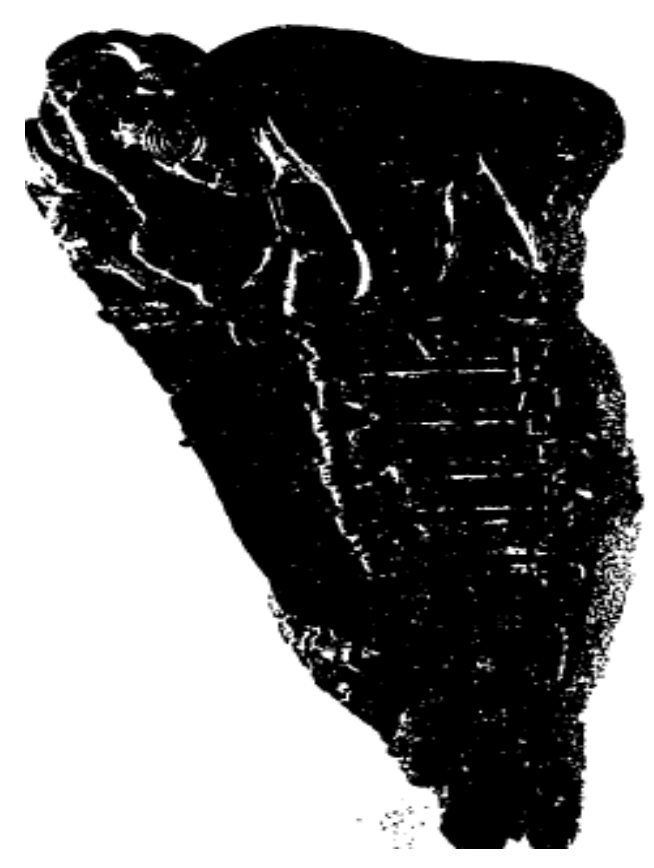

Fig.

15 

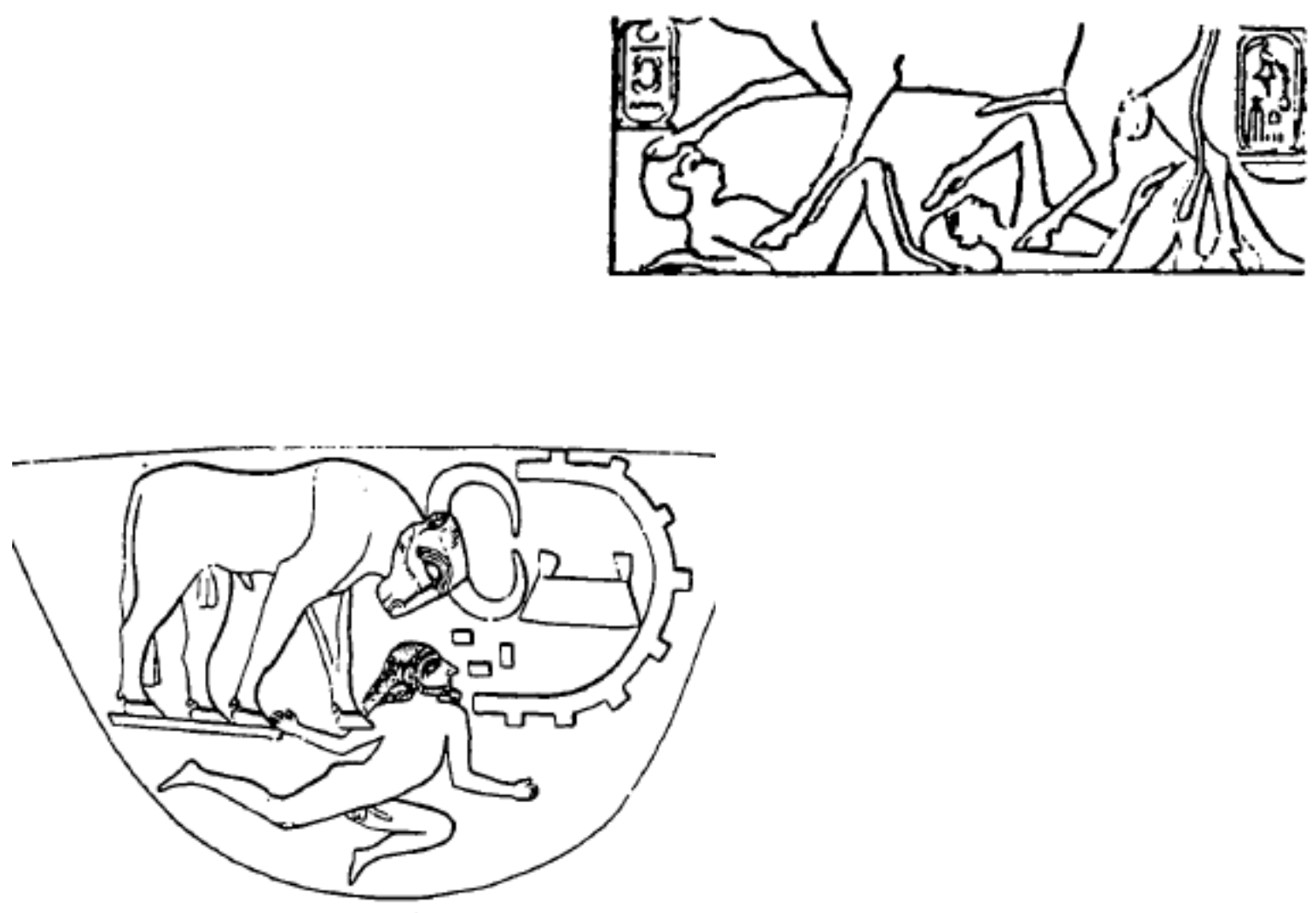

Fig.16

Fig. 17

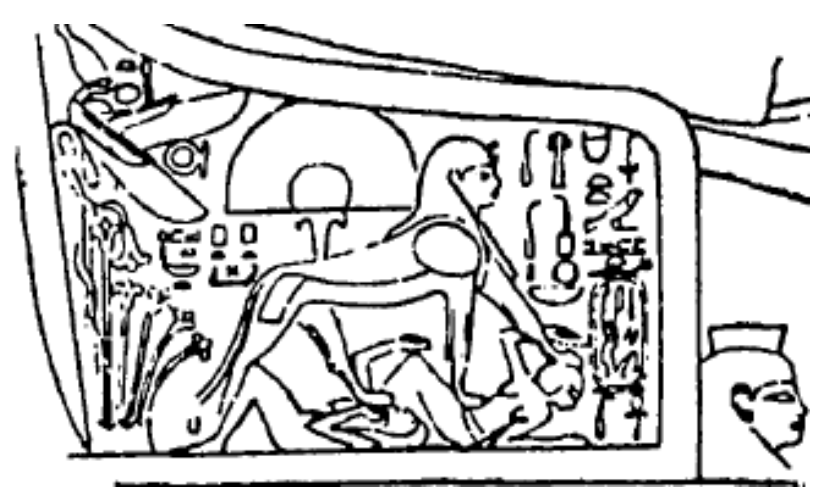




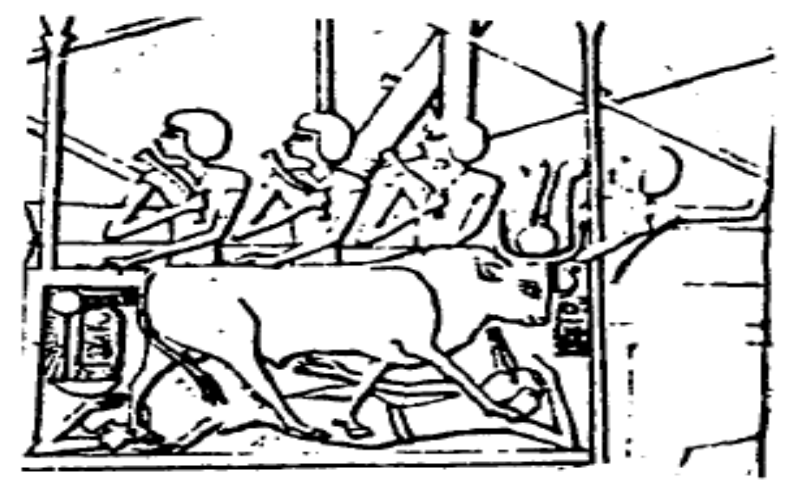

Fig.18

Fig. 19

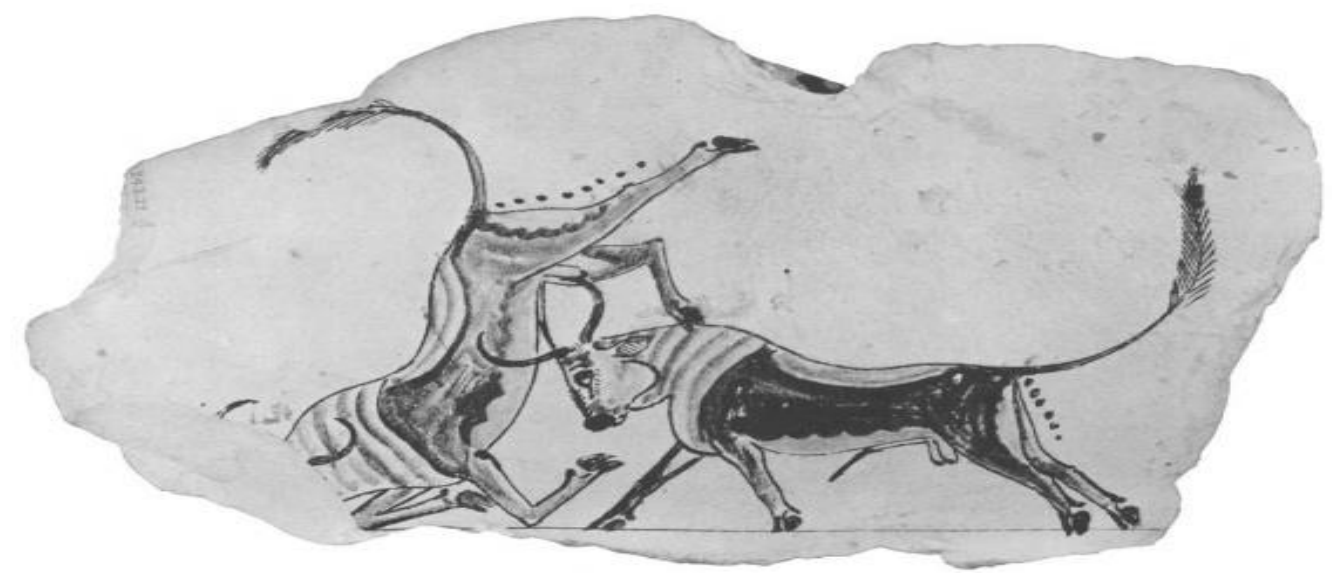

Fig.20

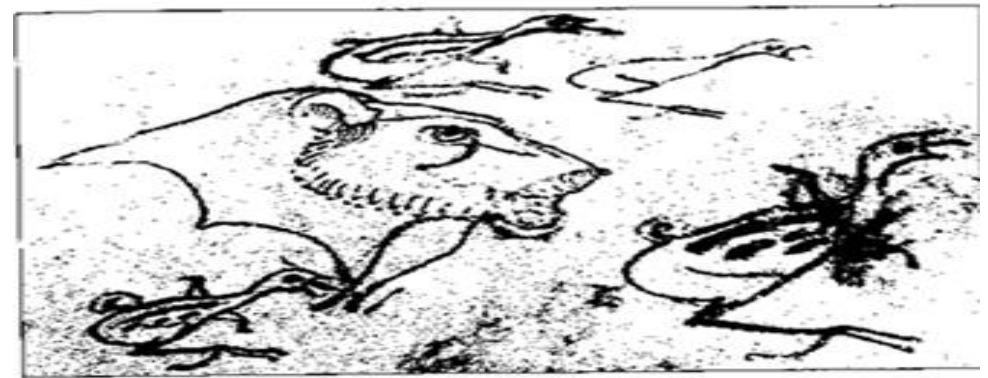

Fig.21 

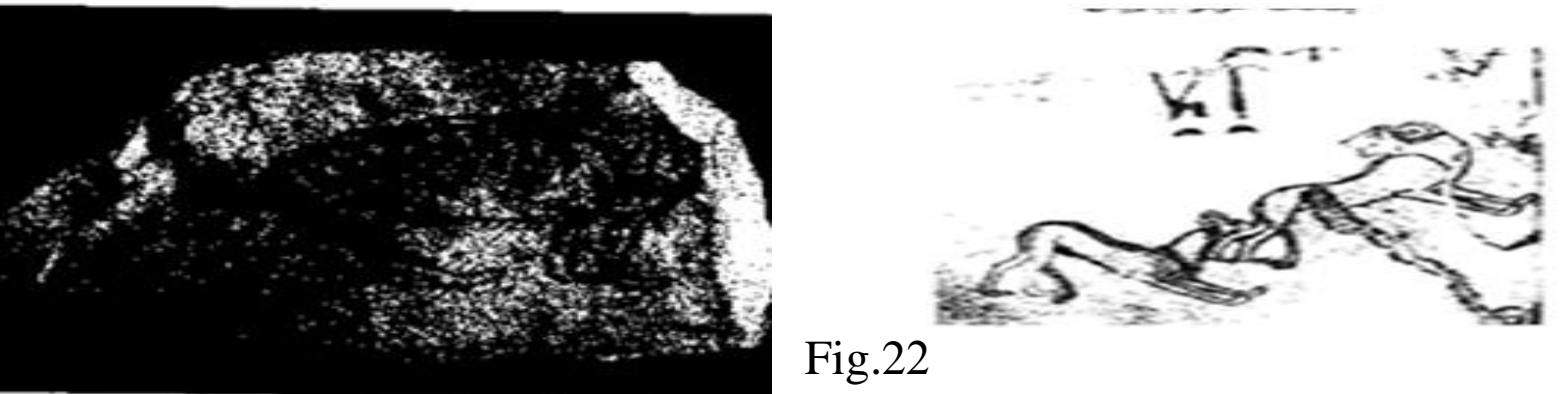

Fig. 22

Fig.23

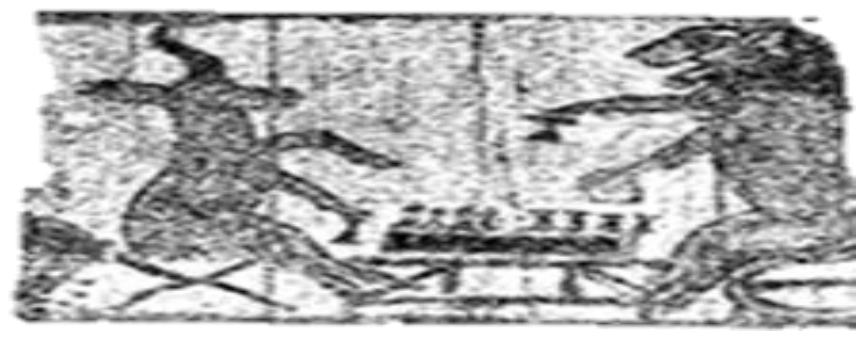

Fig.24

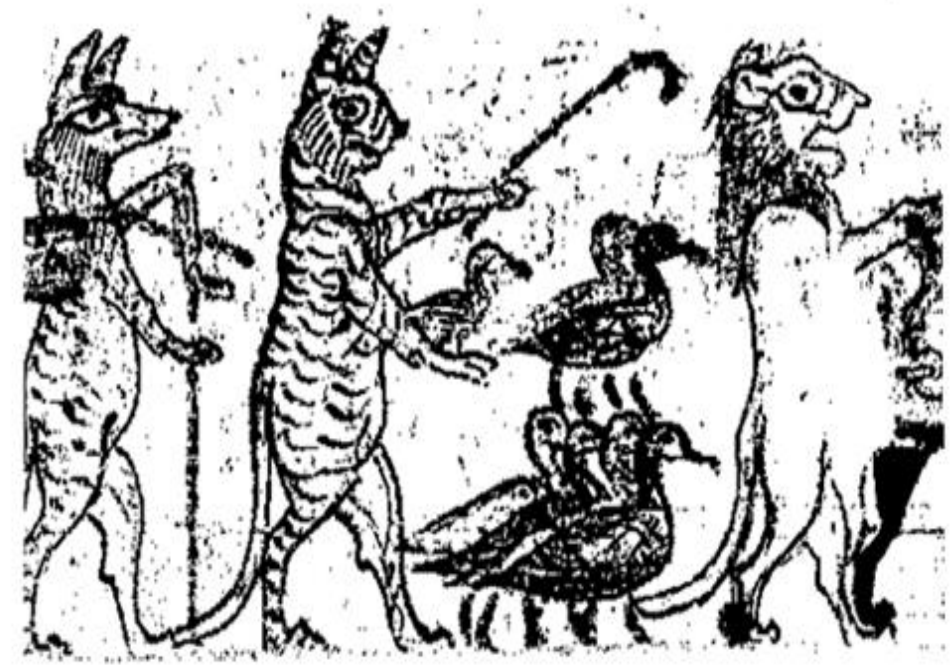

Fig. 25 
1 This study is a part from a dissertation submitted in accordance with the requirements of Minia University for the Master Degree under the title of "Scenes of Political Propaganda Trough the a Aggression Scenes in Ancient Egypt during the New Kingdom" It is under the supervision of Dr. Engy El Kilany (Assis. Prof. of EgyptologyUniversity of Minia).

${ }^{2}$ Houlihan, P. F. (2002). Animals in Egyptian art and hieroglyphs. na.,p 97 143 .

3 te Velde. H.", (1980) A few remarks on the religious significance of animals in ancient Egypt .,p81,82; Teeter, E. (2002). Animals in Egyptian religion. p335-360.

${ }^{4}$ Evans, L. (2010). Animal behavior in Egyptian art: representations of the natural world in Memphite tomb scenes.,p 16.

5 Assmann, J. (1996). The mind of Egypt. Translated by Andrew Jenkins., p 206.

${ }^{6}$ Fischer, H. G. (1977). The Orientation of Hieroglyphs: Part I: Reversals. Metropolitan Museum of Art. p 46-47.

${ }^{7}$ Assmann, J. (1996), op.cit., p206:209 .

${ }^{8}$ Assmann ,J (1994) "Spruch 23 der Pyramidentexte und die Achtung der Feinde Pharaos," p52.

9 Kemp, B. J. (2006). Ancient Egypt: anatomy of a civilization. Psychology Press. p94.

10 O'Connor, D. B., \& Silverman, D. P. (Eds.). (1995). Ancient Egyptian Kingship (Vol. 9). Brill.,p113.

11 Booth, C. (2011). The Ancient Egyptians for Dummies. John Wiley \& Sons. p149.

12 Naydler, J. (2009). The future of the ancient world: Essays on the history of consciousness. Simon and Schuster.,p123.

${ }^{13}$ Wilkinson, J. G. (1841). Manners and Customs of the Ancient Egyptions: Including Their Private Life, Government, Laws, Arts, Manufacturers, Religion, and Early History: Derived from a Comparison of the Paintings, 
Sculptures, and Monuments Still Existing, with the Accounts of Ancient Authors: Illustrated by Drawings of Those Subjects (Vol. 2). J. Murray.p17.

${ }^{14}$ Monteath, M. (2015). Waldron, Melanie: Geography Matters in Ancient Egypt. School Librarian, ,p17.

${ }^{15}$ Riggs, C. (2014). Ancient Egyptian Art and Architecture: A Very Short Introduction. OUP Oxford.,p 85.

${ }^{16} \mathrm{Ibd}, \mathrm{p} 86$.

${ }^{17}$ Payne E.( 2012). , The Pharaohs of Ancient Egypt, New York, p34.

${ }^{18}$ Hodel-Hoenes, S. (2000). Life and Death in Ancient Egypt: Scenes from Private Tombs in New Kingdom Thebes. Cornell University Press., p23. ${ }^{19} \mathrm{Ibd}, \mathrm{p} 23$

${ }^{20}$ Hornung.E. (1980) .The Book of the gates of the afterlife. Aegyptiaca Helvetica., p 134.

${ }^{21}$ Wilkinson, J. G. (1878). The manners and customs of the ancient Egyptians (Vol. 2). J. Murray. pp. 1o3-111.

22 Erman, A. (1894). Life in ancient Egypt. Courier Corporation. P23, Wilkinson, J. G. (1878). Op. cit., p. 103.

${ }^{23}$ Ibd ,p 236.

${ }^{24}$ Peck, W. H. (2013). The material world of ancient Egypt. Cambridge University Press. p 174.

${ }^{25}$ Wilkinson, P. (2009). Myths \& Legends: An illustrated guide to their origins and meanings. Penguin.p235.

${ }^{26}$ Calverley, A. M., \& Broome, M. F. (1933). The Temple of King Sethos I at Abydos, vols. 1. Gardiner (London and Chicago, 1933-35). p1. 30.

${ }^{27}$ Elshamy, M.( 2015).Ancient Egypt :the primal Age of Divine Revelation, Vol I. Library of Congress United states .p62 . 
${ }^{28}$ Helck, W. (1957). . Urkunden des ägyptischen Altertums, vol.. 4.. Urkunden der 18. Dynastie, no. 20 (Berlin: Akademie Verlag1749: 4: f: h't nswt m hb-sd rpi mitt R'wbnf.

${ }^{29}$ Petrie, W. M. F. (2011). The Religion of Ancient Egypt. Cambridge University Press. New York.p30.

30 The sphinx, and who tramples Egypt's traditional enemies parallel with the solar aspects of the sphinx who defeats the forces of chaos in the myth of the murder cat.

${ }^{31}$ Christiane Ziegler. 2002. The Pharaohs. p45.

32 Eugen Rosenstock-Huessy. (2001). I am an Impure Thinker. Argo Books.,p48-49.

${ }^{33}$ Gadalla, M. (2001). Egyptian divinities: The all who are the one. Tehuti Research Foundation.p52.

${ }^{34}$ Homung, E. (1982). Conceptions of God in Ancient Egypt. pp 161-162.

35 - Ockinga, B. (1984). Die Gottebenbildlichkeit im alten Ägypten und im alten Testament. Harrassowitz.pp35-36.

${ }^{36}$ Nelson, H. H. (1981). The Great Hypostyle Hall at Karnak (Vol. 106). Oriental Institute of the Universtity of Chicago. p1. 238.

37 -this is a metaphoric interpretation of the sun rise incident.

${ }^{38}$ Robins, G(2008). The art of ancient Egypt.p136.

${ }^{39}$ Darnell, J. C., \& Manassa, C. (2007). Tutankhamun's armies: battle and conquest during ancient Egypt's late eighteenth dynasty. John Wiley \& Sons.p79

${ }^{40}$ Calverley, A. M., \& Broome, M. F. (1933). The Temple of King Sethos I at Abydos, vols. 1. Gardiner (London and Chicago, 1933-35).p1. 32. 
${ }^{41}$ Geraldine, P. (2002). Handbook of Egyptian mythology. Santa Barbara, Calif: ABC-CLIO.p123.

42 Rice, M. (1998). The Power ofthe Bull. London and New York: Routledge.p146.

${ }^{43}$ Bunson, M. (2002). Encyclopedia of Ancient Egypt (Revised Edition); Facts On File. Inc. New York, NY, 221-222.p151.

${ }^{44}$ O'Connor, D. B., \& Silverman, D. P. (Eds.). (1995). Ancient Egyptian Kingship (Vol. 9). Brill.p112.

${ }^{45}$ Leakey, R.( 2003). Great Civilizations. p47.

46 Booth, C. (2007). The Ancient Egyptians for Dummies. John Wiley \& Sons. p149.

${ }^{47}$ Wilkinson, T. A. (2010). The Rise and fall of Ancient Egypt: The History of a Civilization from $3000 \mathrm{BC}$ to Cleopatra. London, England:

Bloomsbury.p50.

$$
\begin{aligned}
& 48 \text { وليم هـ ـ بيك.(1932) فن الرسم عند قدماء المصريين.الصوره } 102 \text { ـ } \\
& 49 \text { المرجع السابق ص } 279 .
\end{aligned}
$$

${ }^{50}$ For a detailed information about the purposes of the animals representation through the new kingdom see Chapter three ,p 134-139. 